\title{
PANDANGAN RELIGIUS MENGENAI AUTISME
}

\author{
(Autism in Religion Views) \\ DWI SARI USOP') DAN M. FATCHURAHMAN ${ }^{2)}$ \\ 1) Program Studi Pendidikan Guru Sekolah Dasar Fakultas Keguruan dan IImu Pendidikan \\ 2) Program Studi Bimbingan dan Konseling Fakultas Keguruan dan IImu Pendidikan \\ Universitas Muhammadiyah Palangkaraya \\ JI. RTA Milono Km.1,5 Palangka Raya, Kalimantan Tengah 73111 \\ e-mail : sari_1stlove@yahoo.com; dwisari.usop@umpalangkaraya.ac.id; \\ mfatchurahman789@gmail.com
}

\begin{abstract}
The existence of autism is a sign of greatness of Allah swt. that must be considered positive. The presence of children with autism as a lesson for all mankind in treating others. As other children, persons with autism are also required to study religion, run, and practice the rules of religion.
\end{abstract}

Keywords: religion, autism

\section{ABSTRAK}

Keberadaan autisme merupakan suatu tanda kebesaran Allah swt. yang harus dipandang positif. Hadirnya anak-anak autisme sebagai pembelajaran bagi seluruh umat manusia di dalam memperlakukan orang lain. Sebagaimana anak-anak lainnya, penyandang autisme juga wajib belajar agama, menjalankan, serta mengamalkan aturan agama.

Kata kunci : religius, autisme

\section{PENDAHULUAN}

Berbicara tentang autisme sangat menyenangkan tetapi juga menyedihkan. Bagaimana tidak, seseorang yang menyandang autisme mengalami gangguan perkembangan yang kompleks. Mereka mengalami hambatan dalam interaksi sosial, komunikasi, dan perilaku. Padahal, interaksi sosial, komunikasi, dan perilaku merupakan aspek yang sangat penting di dalam menjalin hubungan antar individu dan menjalin hubungan dengan diri sendiri. Hambatan persepsi juga salah satu yang dialami penyandang autisme dan berpengaruh terhadap hambatan lainnya.
Mulai dari ditemukannya autisme sampai saat ini berbagai topik telah dikupas. Definisi, karakteristik, penyebab, penanganan, pendidikan, peran orang tua, keluarga, teman, masyarakat, pendidik, dan pakar kesehatan terhadap penyandang autisme, serta pengembangan alatalat tes untuk mendeteksi autisme. Sampai saat ini, berbagai upaya untuk mengembangkan kemampuan dan keterampilan penyandang autisme terus ditingkatkan. Hal ini dilakukan agar mereka mampu mengurus dirinya sendiri dan mampu memenuhi kebutuhan hidup saat usia dewasa tanpa ketergantungan pada orang lain. 
Dibalik rasa pesimis dan sikap putus asa orang tua maupun keluarga mengenai masa depan penyandang autisme tersimpan harapan dan keyakinan bahwa mereka memiliki kemampuan untuk hidup mandiri dan melakukan berbagai hal layaknya individu pada umumnya. Hal ini menimbulkan motivasi dan membangun resiliensi orang tua untuk berupaya mengembangkan kemampuan dan ketrampilan penyandang autisme di dalam menghadapi kehidupan di masa depan. Dukungan dari berbagai pihak disertai optimisme bahwa autisme dapat disembuhkan merupakan suatu keyakinan yang membantu.

Banyak pakar dari berbagai disiplin ilmu, baik eksak maupun sosial yang tertarik menangani penyandang autisme. Islam adalah salah satu dari beberapa agama yang ada di dunia. Islam tidak dapat disebut sebagai suatu disiplin ilmu, tetapi seluruh yang ada di dalamnya merupakan suatu ilmu yang bermanfaat bila individu yang menganut agama Islam mampu melaksanakan hal yang tertuang di dalam Al Qur'an dan Al Hadits secara benar

\section{PEMBAHASAN}

\section{Autisme}

Sampai saat ini jumlah penyandang autisme terus meningkat. Peningkatan tersebut terlihat dari prevalensi autisme mengalami peningkatan secara global (Neik, Lee, Low, Chia \& Chua; 2014). Hasil riset di dalam DSM IV TR ${ }^{\text {TM }}$ (2000) menyebutkan berdasarkan hasil riset epidemiologi, rata-rata dari 10.000 individu ditemukan 5 kasus autisme atau dari 10.000 individu yang di dalamnya terdapat 20 kasus,
2 kasus adalah kasus autisme. Santosa (2003), menyebutkan insidensi autisme di USA, Inggris, Timur Tengah, dan Asia, insidensi autisme sebesar 1 : 250 anak. Neik, dkk (2014), menyatakan peningkatan prevalensi autisme di Amerika Serikat. Kondisi pada tahun 2006, dari 110 anak ditemukan 1 anak mengalami autisme. Jumlah ini meningkat pada tahun 2008, yakni 1 anak mengalami autisme dari 88 anak.

Sementara itu, prevalensi atau insidensi penyandang autisme di Singapura dan Malaysia tidak dapat dikatakan dengan pasti totalnya. Walaupun demikian, Department of Child Development, Kendang Kerbau Women's and Children's Hospital (KKH) di Singapura mengungkapkan bahwa diagnosis Autism Spectrum Disorders (ASD) adalah hal yang umum (Lian et al. dalam Neik dkk., 2014). Sedangkan di Malaysia, fakta jumlah penyandang autisme mengalami peningkatan tidak bisa dipungkiri. Menurut National Autism Society of Malaysia (NASOM) dalam The National Autism Society of Malaysia, telah terjadi peningkatan $30 \%$ individu dengan autisme dalam tiga tahun terakhir (Cheong dalam Neik dkk., 2014).

Hal yang sama juga terjadi di Indonesia, menurut JPNN.com (2013), pemerintah merilis data jumlah anak penyandang autisme bisa berada di kisaran 112 ribu jiwa. Sedangkan Klinik Autis Online memperkirakan tahun 2015 diperkirakan 1 per 250 anak mengalami gangguan spektrum autis sehingga diduga terdapat kurang lebih 12.800 anak penyandang autisme di Indonesia.

Setiap individu memiliki karakteristik khas yang membedakan dirinya dengan individu lainnya. Demikian pula penyandang autisme. 
Berbeda-beda antara penyandang autisme satu dengan penyandang autisme lainnya walaupun memiliki ciri khas umum yang sama. Ciri khas umum tersebut adalah adanya hambatan di dalam interaksi sosial, komunikasi dan perilaku. Ketiga hambatan ini menyebabkan individu lain mengalami kesulitan didalam menyampaikan pesan yang mampu diterima oleh penyandang autisme secara baik. Kesulitan memahami karakteristik penyandang autisme yang khas juga dirasakan. Hal ini disebabkan mereka tampak memiliki dunianya sendiri. Tidak ada kontak mata saat diajak berbicara, tidak senang disentuh orang lain, berbicara sendiri, suka membeo atau menirukan ulang apa yang dikatakan orang terhadapnya, memiliki ritual atau hobi yang berbeda dan tidak bermanfaat bagi orang lain. Misalnya, senang bermain air, bermain gayung, berputar-putar, minta digendong berkali-kali. Karakteristik khas lainnya dapat berhubungan dengan emosi dan persepsi. Beberapa penyandang autisme memiliki karakteristik agresif, hiperaktif. Ada pula yang hipoaktif. Selain itu, sebagian penyandang autisme memiliki ketidakmampuan berbicara dengan jelas.

Sehubungan dengan hal tersebut, penyebab autis sebelum dapat diketahui secara pasti. Hasil riset yang dinyatakan di dalam jurnal maupun buku menyatakan faktor genetik dan lingkungan (Winarno, 2013 dan Hani'ah, 2015), radang otak, mutasi gen, infeksi virus (Ratajczack, 2011), disfungsi metallothionein dan keracunan logam berat (Santosa, 2003) sebagai penyebab autisme. Kondisi ini memberikan pengaruh terhadap bagian-bagian otak tertentu, seperti cerebral cortex, basal ganglia, brain stem, corpus callosum, cerebellum, amygdala, dan hippocampus. (Winarno, 2013). Bagian-bagian ini berperan penting di dalam merespon stimulus dan menjalankan fungsinya yang meliputi fungsi kognitif, afektif, dan psikomotorik. Sederhananya adalah menjalankan peran didalam berpikir, merasakan sesuatu, serta berperilaku sesuai dengan pikiran dan perasaan.

Selain itu, faktor budaya disebutkan memiliki pengaruh yang menentukan seseorang menyandang autisme maupun di dalam penanganannya. Helms \& Cook (dalam EnnisCole, 2013), menyatakan budaya yang dimaksud adalah nilai-nilai, kepercayaan-kepercayaan, bahasa, ritual, tradisi, maupun perilaku-perilaku yang berlaku umum di suatu kelompok masyarakat. Griffen, Peters, \& Smith (dalam Ennis-Cole, 2013), menyebutkan faktor budaya ini membentuk diri individu dan kepercayaan keluarga mengenai disabilitas, termasuk autisme. Sebagian masyarakat Anglo-Amerika meyakini bahwa faktor imunisasi dan beberapa elemen fisik menyebabkan autisme. Sedangkan pada umumnya masyarakat Afrika-Amerika mempercayai isu-isu yang tidak berhubungan dengan tradisi menjadi penyebab autisme. Isu-isu tersebut adalah diet, proses makan, pengolahan makanan, dan kontaminasi sebagai penyebabnya. Masyarakat Asia-Amerika mempercayai autisme dan disabilitas lainnya sebagai hukuman karena melanggar aturan agama, etika, atau budaya atau ketidakharmonisan antara yin dan yang. Selain itu, beberapa ibu dari daerah Latino memandang autisme sebagai sesuatu yang positif, yakni hadirnya autisme merupakan berkat dan karunia dari Allah yang memberikan 
kesempatan bagi mereka untuk menjadi lebih berguna dan mengorbankan bagian dari hidupnya untuk melayani orang lain (Ennis-Cole, 2013).

\section{Penghayatan Ke-Islaman Masyarakat Hidup Bersama Penyandang Autisme}

Sesuai pandangan Islam semua umat wajib melaksanakan perintah Allah swt. dan menjauhi laranganNya, tidak terkecuali penyandang autisme. Setiap masalah yang menimpa umat manusia, ada jalan keluarnya. Allah swt. berfirman dalam Al Qur'an Surat Al Fatihah ayat 5-6, yakni : "Hanya kepada Engkaulah kami menyembah dan hanya kepada Engkaulah kami memohon pertolongan; Tunjukilah kami jalan yang lurus". Allah swt. juga berfirman dalam Al Qur'an Surat Az Dzariaat ayat 59 yang berbunyi "dan segala sesuatu kami ciptakan berpasangpasangan supaya kamu mengingat kebesaran Allah". Dengan demikian, segala sesuatu yang ada di dunia ini ada pasangannya. Begitu pula dengan autisme yang dikenal sebagai suatu gangguan perkembangan yang terjadi pada anak di bawah usia 3 tahun, akan ada petunjuk untuk mengatasinya. Sesuai dengan firman Allah swt., surat Asy-Syuara ayat 80 yang berbunyi "dan apabila aku sakit. Dialah yang menyembuhkan aku".

Mengacu pada firman Allah swt. tersebut di atas, banyak kajian mengenai autisme. Tidak terkecuali kajian islami tentang autisme. Abas, Othman, \& Daud (2014), mengembangkan software untuk membantu membimbing anak dalam melaksanakan sholat yang mana aplikasi ini menggunakan pendekatan Treatment and Education of Autistic and Related Communication Handicapped Children (TEACCH). Melalui penggunaan aplikasi ini, diharapkan, anak-anak autis yang mengalami kesulitan di dalam menghafalkan ayat-ayat Al 'Qur'an mampu secara perlahan mampu menghafal dan memahami ayatayat Al Qur'an serta mampu mempraktekkan sholat dengan benar.

Tumiran, Mohamad, Saat, Yusoff, Rahman, \& Adli (2013), menyatakan bahwa anak-anak penyandang autisme dapat mengalami masalah dalam tidur yang berhubungan dengan kualitas tidur yang rendah, juga sering terbangun tengah malam, dan atau mengalami insomnia. Hal ini mempengaruhi kondisi emosi dan perilaku anak autisme. Anak menjadi agresif, tantrum, serta menciderai diri sendiri. Tumiran dkk. (2013), mengemukakan bahwa untuk membantu mengatasi gangguan tidur yang dialami, maka Qur'anic Sound Therapy dapat memberikan efek yang positif bagi anak-anak penyandang autisme. Layaknya, terapi musik, Qur'anic Sound Therapy dengan cara membacakan atau memperdengarkan lantunan ayat-ayat Al Qur'an dapat mempengaruhi kondisi psikologis seseorang. Hal ini disebabkan pembacaan Al Qur'an berperan sebagai terapi bicara dan juga relaksasi (Tumiran, dkk. 2013).

Senada dengan Tumiran, dkk (2013), Hady, Wahyuni \& Purwaningsih (2012), mengemukakan bahwa terapi musik murottal mampu meningkatkan perkembangan kognitif anak autis. Peningkatan ini lebih baik daripada anak mendengarkan musik klasik. Hasil penelitian menunjukkan bahwa sebelum dilakukan terapi musik klasik maupun terapi musik murottal, tingkat perkembangan kognitif anak autis berada di level yang sama. Setelah anak 
menjalani terapi, perkembangan kognitif kelompok anak autisme yang mengikuti terapi musik murottal jauh lebih tinggi prosentasenya, yaitu $64,39 \%$. Sedangkan kelompok anak autisme yang mengikuti terapi musik klasik mengalami peningkatan perkembangan kognitif sebesar $27,59 \%$.

Berbeda dengan Hady, Wahyuni, \& Purwaningsih (2012), Abas, Othhman, \& Daud (2014) dan Tumiran dkk. (2013), Jegatheesan, Miller, \& Fowler (2010), menekankan bahwa keimanan kepada Allah swt. memunculkan penerimaan terhadap keadaan anak yang menyandang autisme, harapan-harapan terhadap anak, dan mengasuh anak sendiri. Penerimaan tampak dari pandangan dan pemahaman orang tua tentang autisme, baik dari sisi moral dan resiliensi, Allah swt. sebagai pelindung anak, nasib dan karma yang berhubungan dengan anak, serta tujuan orang tua dalam pendidikan anak sehari-hari dan pendidikan anak dalam memahami bahasa. Penelitian terhadap 3 (tiga) orang tua yang anaknya mengalami autis. Ketiga orang tua yakin bahwa memiliki anak autisme merupakan hadiah yang diberikan Allah swt. dan Allah swt. akan melindungi anaknya. Mereka yakin bahwa kondisi anak memiliki keterkaitan dengan dirinya dan mereka yakin bahwa Allah swt. menganggap mereka mampu untuk mendidik anak dengan baik. Selain itu, mempelajari bahasa yang berbeda-beda juga sangat penting untuk mengembangkan kemampuan anak berinteraksi dengan orang lain. Khususnya, saat melaksanakan ibadah bagi kaum muslim.

\section{KESIMPULAN}

Memandang autisme secara religi, maka dapat disimpulkan bahwa :

a. Aplikasi sholat menggunakan pendekatan TEACCH diharapkan dapat membantu penyandang autisme menghafal ayat-ayat Al Qur'an dan mempraktekkan sholat.

b. Terapi musik dalam murottal lebih meningkatkan perkembangan kognitif penyandang autisme daripada terapi musik Mozart.

c. Membaca Al Qur'an dapat berfungsi sebagai terapi dan memberikan ketenangan sehingga diharapkan dapat membantu mengatasi gangguan tidur yang dialami penyandang autisme.

d. Keyakinan terhadap Allah swt. memunculkan penerimaan orang tua penyandang autisme.

\section{DAFTAR PUSTAKA}

Abas, H; Othman, H; \& Daud, S.M. 2014. Islamic Studies for Disabled : Teaching Salat for Autism Using APPS. Oasis International Conference on Islamic Education (OICIE). https://www.researchgate.net/profile/Hafiza Abas2/publication/276279328_ISLAMIC STUDIES FOR DISABLED TEACHING S ALAT FOR AUTISM USING APPS/links/ 555566e908ae6fd2d821 cec4.pdf

Diagnostic and Statistical Manual of Mental Disorders. 2000. Fourth Edition. Washington, DC : American Psychiatric Association

Ennie-Cole, D; dkk. 2013. The Impact of Culture on Autism Diagnosis and Treatment : Considerations for Counselorsand Other Proffesionals. The family Journal : Counseling and Therapy for Couples and families. Vol 2, No. 3, Pp 279-287 
Hady, N.A.; Wahyuni; \& Purwaningsih, W. 2012. Perbedaan Efektivitas Terapi Musik Klasik dan Terapi Musik Murottal terhadap Perkembangan Kognitif Anak Autis di SLB Autis Kota Surakarta. GASTER, Vol. 9, No. 2, Pp. 72-81

Hani'ah, M. 2015. Kisah Inspiratif anak-anak Autisme Berprestasi : Autisme dan Tips-tips Menjadikan Anak Autis Berprestasi. Yogyakarta : DIVA Press.

Jegatheesan, B; Miller, P.J., \& Fowler, S.A. 2010. Autism from a Religious Perspective : A Study of Parental beliefs in South Asian Muslim Immigrant Families. SAGE. V0I. 25, No. 2, Pp. 98-109

JPNN.com. 2013. Penderita Autisme di Indonesia Terus Meningkat. http://www.jpnn.com/news/penderitaautisme-di-indonesia-terus-meningkat. (Diakses 08 Januari 2015)

Klinik Autis. Online. Jumlah Penderita Autis di Indonesia. https://klinikautis.com/2015/09/06/jumlahpenderita-autis-di-indonesia/ (Diakses 08 Januari 2015)

Neik, T.T.X., dkk. 2014. Prevalence, Diagnosis, and Research on Autism Spectrum Disorders $(A S D)$ in Singapore and Malaysia. International Journal of Special Education. Vol. 29, No. 3, Pp. 82-92

Ratajczak, Ratajczak, V.H. 2011. Theoretical Aspects of Autism: Causes - a Review. Journal of Immunotoxicology, Vol. 8, No. 1. Pp. 68-79

Santosa, Slamet. 2003. Peran Metallothionein pada Autisme. JKM, Vol. 2. No. 2. Pp. 2330

Tumiran, M.A; Mohamad, S.P; Saat, R.M; Yusoff, M.Y.Z.M; Rahman, N.N.A; \& Adli, D.S.H. 2013. Adressing Sleep Disorder of Autistic Children with qur'anic Sound Therapy. Health. Vol. 5, No. 8A2, Pp. 7379.

Winarno, F.G. 2013. Autisme dan Peran Pangan. Jakarta : PT. Gramedia Pustaka Utama. 